\title{
Prediction of Motivation to Help, Achievement Motivation and Social Appreciation as Elements of Customer Orientation through Selected Personality Traits among Traders
}

\author{
Tatiana Lorincová1*, Anna Tomková1 \\ ${ }^{1}$ Department of Managerial Psychology, Faculty of Management, Prešov University of Prešov, \\ Konštantínova 16, 080 01, Prešov, Slovakia \\ * Corresponding author, e-mail: tatiana.lorincova@unipo.sk
}

Received: 17 October 2018, Accepted: 14 June 2019, Published online: 28 November 2019

\begin{abstract}
This contribution analyzes motivation to help, achievement motivation and social appreciation through verification of predictive power selected personality traits (neuroticism, extraversion, openness to experience, agreeableness and conscientiousness). The research sample is based on traders from the Slovak republic and Ukraine, working in both private and public organizations. The research data were collected through SKASUK (Customer orientation scale by Sonnenberg iand NEO (Five factories Inventory)). Based on the confirmed aspects we came to the conclusion that the selected personality traits have no significant predictive power in predicting motivation to help, achievement motivation and social appreciation.
\end{abstract}

Keywords

motivation to help, achievement motivation, social appreciation, personality traits, traders

\begin{abstract}
1 Introduction
Customer orientation can be defined as: "the set of behavior and beliefs that places a priority on customers' interests and continuously creates superior customer value" (Rindfleischand Moorman, 2003). Saxe and Weitz (1982) coined this concept of salesperson customer orientation in 1982, and customer orientation has been a topic of much interest over the last three decades. The reason for the widespread interest in this topic is that it is widely accepted that customer orientation should positively influence important psychological outcomes (e.g. job satisfaction and organizational commitment) (Donavan et al., 2004; Farrell and Oczkowski, 2009), as well as job-related outcomes (e.g. performance) (Baydoun et al., 2001; Jones et al., 2003) among frontline employees. Many researchers are in agreement that managers should consider customer orientation as an important criterion in frontline employee decisions (Zablah et al., 2012), particularly as the service sector continues to grow and companies continually put more emphasis on customer-oriented operations (Baydoun et al., 2001).
\end{abstract}

\subsection{Customer orientation}

Customer orientation is often contrasted with sales-oriented selling. The key differences between these two orientations is that whereas customer orientation focuses on assisting customers to satisfy their long-term wants and needs, a sales orientation puts the selling organization and/or salesperson before the customer (Jones et al., 2003). Thus, a person with a high customer orientation would avoid actions that could potentially sacrifice customer interest to instead try to make an immediate sale (Saxe and Weitz, 1982). It has been widely documented in the literature that customer orientation leads to greater long-term performance benefits for the salesperson compared to when they have a sales orientation (Thakor and Joshi, 2005). However, it should be noted that people often persist in being sales-oriented due to the additional effort that is required to have a customer orientation (Saxe and Weitz, 1982). It is easier to have a sales-orientation than the more beneficial customer orientation.

It should be noted that customer orientation has been found to be an enduring disposition (i.e., consistent over time), thus lending support to the notion that selecting candidates based on this surface-level personality trait is an effective approach (Farrell and Oczkowski, 2009; Grizzle et al., 2009). Farrell and Oczkowski (2009) write: "without a doubt, our results suggest that it is important to 
hire employees who have a customer orientation" (p. 161). Additionally, using customer service orientation measures in selection should result in very minimal to no adverse impact on minority applicants (Frei and McDaniel, 1998).

\subsection{Personality traits}

Ones and Viswesvaran (1996) and Frei and McDaniel (1998) both found that customer orientation measures correlate with the Big Five measures of agreeableness, emotional stability, and conscientiousness. Thus, due to the empirical support for these constructs making up the broader construct of customer orientation, these will be the dimensions that are measured in this new scale of customer orientation, which in this study was designed specifically for security guards.

The Big Five personality factor of agreeableness includes such traits as being trusting, cooperative, and mature (Frei and McDaniel, 1998). Customer service has been found to have a correlation of 0.43 with the Big Five measure of agreeableness (Frei and McDaniel, 1998). Additionally, agreeableness was also included as one of three dimensions of Hogan, Hogan, and Busch's well-known measure of customer orientation (Brown et al., 2002). Agreeableness is related to customer orientation because agreeableness leads the employee to engage in friendly, rather than confrontational conversations with customers; something that is clearly valued by organizations that prioritize customer service (Hennig-Thurau and Thurau, 2008).

Agreeableness has indeed been found to be a significant predictor of the customer orientation of front-line employees and also predicted their overall job performance. Emotional stability refers to the degree to which a person's emotions vary widely (Brown et al., 2002). Individuals who have low levels of emotional stability are often highly strung, stress prone, moody, lack self-esteem, and are insecure (Barrick and Mount, 2009); all of which are problematic characteristics for those working as a security guard. Intuitively, a person that is emotionally unstable would have a fluctuating desire to serve customers and meet their needs (Brown et al., 2002). Emotional stability has been found to have a correlation to customer orientation of 0.37 . The sub-scales of emotional stability that will be assessed in the Customer Orientation Scale are: anger, vulnerability, and self-consciousness.

Conscientiousness includes such components as orderliness and striving to achieve (Frei and McDaniel, 1998) and conscientious individuals are hardworking, dependable, responsible, careful, and reliable (Barrick and
Mount, 2009). Conscientiousness has been found to predict job performance, regardless of occupational category (Frei and McDaniel, 1998). This shows the powerful influence that conscientiousness can have on a person's success in their job. Conscientiousness has been found to have a correlation of 0.42 with customer service (Frei and McDaniel, 1998). One study specifically found that logistics employees with higher levels of conscientiousness had a greater likelihood of satisfying the needs of both internal and external customers (Periatt et al., 2013). The sub-components of conscientiousness that are relevant to customer orientation and that will be assessed in this measure include: self-efficacy, dutifulness, cautiousness, and self-discipline. Ones and Viswesvaran (1996) found that conscientiousness and emotional stability were the strongest personality correlates of customer orientation (Barrick and Mount, 2009). This is the main reason for focusing our research on analysis of customer orientation and selected personality traits of traders.

\section{Methodology}

The main goal of the research study is to analyze motivation to help, achievement motivation and social appreciation (customer orientation characteristics) through verification of the predictive power of selected personality traits (neuroticism, extraversion, openness to experience, agreeableness and conscientiousness).

Hypothesis 1: We hypothesize that selected personality traits contribute to prediction of motivation to help to a significant degree.

Hypothesis 2: We assume that selected personality traits contribute to predicting achievement motivation to a significant extent.

Hypothesis 3: We assume that selected personality traits contribute to the prediction of social appreciation to a significant extent.

\section{Research sample}

The research sample consisted of 116 respondents aged from 19 to 30 years (the average age was 24.56 with a standard deviation 2.97). The proportionality of gender was uneven- the sample consisted of63 women and 53 men. The research sample consisted of 58 Slovak and 58 Ukrainian respondents, who work as traders. Respondents were selected by using intentional selection. An important condition was to find a balanced sample of traders from both Slovakia and Ukraine. Table 1 shows the descriptive data of the selected variables. 
Table 1 Descriptive statistics of variables

\begin{tabular}{lllll}
\hline Personality traits & $\mathrm{M}$ & $\mathrm{SD}$ & $\mathrm{N}$ \\
\hline 1 & Neuroticism & 2.10 & 0.41 & 116 \\
2 & Agreeableness & 2.92 & 0.41 & 116 \\
3 & Extraversion & 1.99 & 0.44 & 116 \\
4 & Openness to experience & 1.92 & 0.45 & 116 \\
5 & Conscientiousness & 2.01 & 0.42 & 116 \\
\hline Customer orientation characteristics & $\mathrm{M}$ & $\mathrm{SD}$ & $\mathrm{N}$ \\
\hline 6 & Motivation to help & 0.49 & 0.13 & 116 \\
7 & Achievement motivation & 0.50 & 0.13 & 116 \\
8 & Social appreciation & 0.47 & 0.12 & 116 \\
\hline
\end{tabular}

\section{Research methods}

We used two self-reported questionnaires for the research: SKASUK developed by Sonnenberg and the NEO-FFI questionnaire developed by Loehlin et al. (1998).

\subsection{SKASUK- Customer orientation scales}

We used a standardized questionnaire called the Customer orientation scale (SKASUK) developed by H. G. Sonnenberg, translated by Kováč (2006). The SKASUK questionnaire contains 94 statements and it consists of four motivational and four compensatory scales. The individual entries are rated by selecting number $1=$ agree with statement and number $0=$ disagree with statement.

The motivational scales consist of four motives:

- social appreciation, including social motivation,

- motivation to help including motivation to be of service,

- achievement motivation, including the motive of performance,

- dominance, including the motive of power.

The compensatory scales consist of four scales:

- extraversion involves the ability to access other people,

- frustration tolerance involves the ability not to be discouraged by failure,

- empathy involves the ability to be able to feel empowered by others,

- self-observation involves the observation and analysis of own behavior.

\subsection{NEO- Five Factory Inventory}

The Five Factor Inventory is a well-known methodology which measures personality traits (the level of extraversion, agreeableness, conscientiousness, neuroticism, and openness to experience), created by Loehlin et al. (1998) in Slovak translation by Hřebičková and Urbánek (2001).
The Five Factor Inventory contains 34 items, which are considered on a 5 point scale (1- strongly disagreement, 5strongly agreement). The Five Factor Inventory consists of 5 personality factors or traits:

Extraversion: is characterized by excitability, sociability, talkativeness, assertiveness and high amounts of emotional expressiveness.

Agreeableness: This personality dimension includes attributes such as trust, altruism, kindness, affection and other prosocial behaviors. People who are high in agreeableness tend to be more cooperative while those low in this trait tend to be more competitive and even manipulative.

Conscientiousness: The standard features of this dimension include high levels of thoughtfulness, with good impulse control and goal-directed behaviors. Those high in conscientiousness tend to be organized and mindful of details.

Neuroticism: Neuroticism is a trait characterized by sadness, moodiness, and emotional instability. Individuals who are high in this trait tend to experience mood swings, anxiety, moodiness, irritability and sadness. Those low in this trait tend to be more stable and emotionally resilient.

Openness to experience: This trait features characteristics such as imagination and insight, and those high in this trait also tend to have a broad range of interests. People who are high in this trait tend to be more adventurous and creative. People low in this trait are often much more traditional and may struggle with abstract thinking (McCrae and Terraciano, 2005).

\section{Research results}

The objective of the research is to analyze motivation to help, achievement motivation and social appreciation (customers orientation characteristics) through verification of the predictive power of selected personality traits (neuroticism, openness to experience, agreeableness, extraversion and conscientiousness) of a selected sample of traders. The results were processed using the statistical program IBM SPSS 20.00 and assessed by linear regression analysis. Table 2 shows the predictive power of the independent variables.

The constructs examined (selected personality traits) accounted for only $4.8 \%$ of the prediction with $R^{2}=0.048$. Neuroticism, openness to experience, agreeableness, extraversion and conscientiousness do not contribute to prediction of motivation to help. Hypothesis 1 was not verified, as we assumed that the selected personality traits significantly contribute to prediction of the motivation to help. Table 3 shows the predictive power of the independent variables. 
Table 2 Prediction of Motivation to help through selected personality traits

\begin{tabular}{lccccc}
\hline $\begin{array}{l}\text { Predictors of } \\
\text { Motivation to help }\end{array}$ & $\mathrm{B}$ & $\begin{array}{c}\text { Std. } \\
\text { Error }\end{array}$ & Beta & $\mathrm{t}$ & $\mathrm{p}$ \\
\hline $\begin{array}{l}\text { Neuroticism } \\
\begin{array}{l}\text { Openness to } \\
\text { experience }\end{array}\end{array}$ & -0.038 & 0.031 & -0.115 & -1.236 & 0.219 \\
$\begin{array}{l}\text { Agreeableness } \\
\text { Extraversion }\end{array}$ & 0.013 & 0.028 & 0.043 & 0.426 & 0.671 \\
$\begin{array}{l}\text { Conscientiousness } \\
\text { (Constant) }\end{array}$ & -0.040 & 0.029 & -0.131 & -1.394 & 0.166 \\
\hline
\end{tabular}

Table 3 Prediction of Achievement motivation through selected personality traits

\begin{tabular}{|c|c|c|c|c|c|}
\hline $\begin{array}{l}\text { Predictors of } \\
\text { Achievement } \\
\text { motivation }\end{array}$ & B & $\begin{array}{l}\text { Std. } \\
\text { Error }\end{array}$ & Beta & $\mathrm{t}$ & $\mathrm{p}$ \\
\hline Neuroticism & 0.034 & 0.031 & 0.103 & 1.100 & 0.274 \\
\hline $\begin{array}{l}\text { Openness to } \\
\text { experience }\end{array}$ & 0.003 & 0.028 & 0.011 & 0.112 & 0.911 \\
\hline Agreeableness & 0.023 & 0.031 & 0.069 & 0.733 & 0.465 \\
\hline Extraversion & -0.031 & 0.029 & -0.101 & -1.075 & 0.285 \\
\hline Conscientiousness & -0.020 & 0.031 & -0.062 & -0.652 & 0.465 \\
\hline (Constant) & 0.484 & 0.136 & & 3.560 & 0.001 \\
\hline
\end{tabular}

The constructs examined (selected personality traits) explained only $7 \%$ of prediction with $R^{2}=0.07$. Neuroticism, openness to experience, agreeableness, extraversion and conscientiousness do not contribute to prediction of achievement motivation. Hypothesis 2 was not verified, as we assumed that the selected personality traits would contribute to a significant degree to prediction of achievement motivation. Table 4 shows the predictive power of the independent variables.

The constructs examined (selected personality traits) explained only $5.3 \%$ of prediction with $R^{2}=0.053$. Neuroticism, openness to experience, agreeableness, extraversion and conscientiousness were not shown to contribute to prediction of social appreciation. Hypothesis 3 was not verified, as we assumed that these personality traits would contribute to a significant extent to prediction of social appreciation.

The preliminary results of our research attempted to investigate the potential to work with customers in the context of personality traits. In the future it may be necessary to extend the research sample and to use another standardized questionnaire which measures personality traits. This would allow a better examination of the personality of the traders.
Table 4 Prediction of Social appreciation through selected personality traits

\begin{tabular}{|c|c|c|c|c|c|}
\hline $\begin{array}{l}\text { Predictors of } \\
\text { Social } \\
\text { appreciation }\end{array}$ & $\mathrm{B}$ & $\begin{array}{l}\text { Std. } \\
\text { Error }\end{array}$ & Beta & $\mathrm{t}$ & $\mathrm{p}$ \\
\hline Neuroticism & 0.012 & 0.028 & 0.041 & 0.433 & 0.666 \\
\hline $\begin{array}{l}\text { Openness to } \\
\text { experience }\end{array}$ & -0.034 & 0.026 & -0.126 & -1.330 & 0.186 \\
\hline Agreeableness & -0.027 & 0.029 & -0.090 & -0.956 & 0.343 \\
\hline Extraversion & 0.011 & 0.027 & 0.039 & 0.415 & 0.679 \\
\hline Conscientiousness & -0.013 & 0.028 & -0.045 & -0.472 & 0.638 \\
\hline (Constant) & 0.571 & 0.126 & & 4.546 & 0.000 \\
\hline
\end{tabular}

\section{Discussion and conclusion}

This section will interpret our research findings, which are related to selected personality traits and customer orientation in the context of selected sample Slovak and Ukrainian traders.

We did not find that the selected personality traits (neuroticism, openness to experience, agreeableness, extraversion and conscientiousness) influenced the motivation to help. Previous research showed that agreeableness has indeed been found to be a significant predictor of the customer orientation of front-line employees and also predicted their overall job performance (Periatt et al., 2013). This may be caused by the method of measuring the personality traits, which do not include the characteristic of motivation to help. On the other hand, our research did not show significant predictive power for agreeableness and other personality traits in relation to motivation to help, which is one of core motivational indicators of customer orientation.

We did not find a significant influence of the selected personality traits (neuroticism, openness to experience, agreeableness, extraversion and conscientiousness) on achievement motivation. It should also be noted that emotional stability and conscientiousness have been found to be the best personality predictors of an individual's longterm motivation levels and subsequent work behaviors (Barrick and Mount, 2009). Achievement motivation as a part of customer orientation is not influenced by personality traits. Previous findings suggested that self-direction and achievement motivational domains represented underlying dimensions in the context of social domains and the characteristics of traders (Swenson and Herche, 1994). Achievement motivation has target-oriented characteristics, which are not hereditary. This appears to be the main reason, why our hypothesis was not demonstrated. 
Achievement of customer orientation is impossible if the employees of an organization do not perceive themselves as being there to serve customers, or recognize that the only reason for their being employed is to help the organization create value for customers. Therefore, total organizational involvement in serving the customer must exist before a true customer orientation can be achieved (Judd, 2003). In the future we could focus on other important characteristics which are related to customer orientation.

We did not find the influence of selected personality traits (neuroticism, openness to experience, agreeableness, extraversion and conscientiousness) on social appreciation. Social appreciation helps individuals to build social bonds to others. Experiences of appreciation enhance the positive mood and feelings of connection of individuals to the appreciated stimulus and to the nature of existence (Adler and Fagley, 2005). It is very surprising that social appreciation is not connected to the selected personality traits, especially to agreeableness. Our findings are not consistent with previous research from Adler and Fagley (2005) who define appreciation as a feature which promotes positive effects, more satisfying relationships and improves the ability to cope with stress (Schneider, 2001). We assumed that personality

\section{References}

Adler, M. G., Fagley, N. S. (2005) "Appreciation: Individual Differences in Finding Value and Meaning as a Unique Predictor of Subjective Well-Being", Journal of Personality, 73(1), pp. 79-114. https://doi.org/10.1111/j.1467-6494.2004.00305.x

Barrick, M. R., Mount, M. K. (2009) "Select Conscientiousness and Emotional Stability", In: Locke, E. A. (ed.) Handbook of Principles of Organizational Behavior, Blackwell Publishers, Hoboken, NJ, USA, pp. 15-28. https://doi.org/10.1002/9781119206422.ch2

Baydoun, R.,Rose, D., Emperado, T. (2001) "Measuring Customer Service Orientation: An Examination of the Validity of the Customer Service Profile", Journal of Business and Psychology, 15(4), pp. 605-620. https://doi.org/10.1023/A:1007823114303

Brown, T. J., Mowen, J. C., Donavan, T., Licata, J. W. (2002) "The Customer Orientation of Service Workers: Personality Trait Effects on Self and Supervisor Performance Ratings", Journal of Marketing Research, 39(1), pp. 110-119. https://doi.org/10.1509/jmkr.39.1.110.18928

Churchill, G. A., Ford, N. M., Hartley, S. W., Walker, O. C. (1985) "The Determinants of Salesperson Performance: A Meta-analysis", Journal of Marketing Research, 22(2), pp. 103-118. https://doi.org/10.1177/002224378502200201 characteristics would predict social appreciation. This finding was surprising and in the future it would be appropriate to extend research to other personality traits in the context of social appreciation.

Swenson and Herche (1994) state that the determinants of success in personal selling have long been a topic of interest of marketing researchers and sales managers. The cumulative results of salesperson performance research indicate that no factor adequately accounts for variations in selling effectiveness (Churchill et al., 1985). The research results presented did not identify personality traits in relation to the characteristic of customer orientation, but in the future it would be worth focusing on achievement and social bonds of traders to customers.

One limitation of the study was the sample size and in the future it would be expedient to expand the research sample into across-cultural research study (including traders from the Visegrad Four countries).

\section{Acknowledgments}

The project presented in this article is supported by 0033PU-4/2017- KEGA Implementation of interpersonal skills in the context of the Psychology of business-innovation of contents and teaching.

Donavan, D. T., Brown, T. J., Mowen, J. C. (2004) "Internal Benefits of Service-Worker Customer Orientation: Job Satisfaction, Commitment, and Organizational Citizenship Behaviors", Journal of Marketing, 68(1), pp. 128-146. [online] Available at: https:// www.jstor.org/stable/30161979 [Accessed: 10 March 2019]

Farrell, M. A., Oczkowski, E. (2009) "Service worker customer orientation, organization/job fit and perceived organization support", Journal of Strategic Marketing, 17(2), pp. 149-167. https://doi.org/10.1080/09652540902879276

Frei, R. L., McDaniel, M. A. (1998) "Validity of Customer Service Measures in Personnel Selection: A Review of Criterion and Construct Evidence", Human Performance, 11(1), pp. 1-27. https://doi.org/10.1207/s15327043hup1101_1

Grizzle, J. W., Zablah, A. R., Brown, T. J., Mowen, J. C., Lee, J. M. (2009) "Employee customer orientation in context: How the environment moderates the influence of customer orientation on performance outcomes", Journal of Applied Psychology, 94(5), pp. 1227-1242. https://doi.org/10.1037/a0016404

Hennig-Thurau, T., Thurau, C. (2008) "Customer Orientation of Service Employees-Toward a Conceptual Framework of a Key Relationship Marketing Construct", Journal of Relationship Marketing, 2(1-2), pp. 23-41. https://doi.org/10.1300/J366v02n01_03 
Hřebičková, M., Urbánek, T. (2001) "NEO pětifaktorovýosobnostníinventář" (NEO Five-factor personality inventory), Hogrefe -Testcentrum, Praha, Czech Republic. (in Slovak)

Jones, E., Busch, P., Dacin, P. (2003) "Firm market orientation and salesperson customer orientation: interpersonal and intrapersonal influences on customer service and retention in business-to business buyer-seller relationship", Journal of Business Research, 56(4), pp. 323-340. https://doi.org/10.1016/S0148-2963(02)00444-7

Judd, C V. (2003) "Achieving a customer orientation using "people-power," the 5th P", European Journal of Marketing, 37(10), pp. 1301-1313.

https://doi.org/10.1108/03090560310487112

Kováč, J. (2006) "How to embrace e-business and make it succeed? Destination CRM", [online] Available at: www.destinationcrm. com [Accessed: 05 March 2019]

Loehlin, J. C., McCrae, R. R., Costa, P. T., John, O. P. (1998) "Heritabilities of Common and Measure-Specific Components of the Big Five Personality Factors", Journal of Research in Personality, 32(4), pp. 431-453. https://doi.org/10.1006/jrpe.1998.2225

McCrae, R. R., Terraciano, A. (2005) "Universal Features of Personality Traits from the Observer's Perspective: Data From 50 Cultures", Journal of Personality and Social Psychology, 88(2), pp. 547-561. https://doi.org/10.1037/0022-3514.88.3.547

Ones, D. S., Viswesvaran, C. (1996) "Bandwidth-fidelity dilemma in personality measurement for personnel selection", Journal of Organizational Behavior, 17(6), pp. 609-626.

https://doi.org/10.1002/(SICI)1099-1379(199611)17:6<609::AIDJOB1828>3.0.CO;2-K
Periatt, J. A., Chakrabarty, S., LeMay, S. A. (2013) "The Selling Orientation-Customer Orientation (Soco) Scale: Cross-Validation of the Revised Version", Journal of Personal Selling and Sales Management, 24(1), pp. 49-54. https://doi.org/10.1080/08853134.2004.10749016

Rindfleisch, A., Moorman, C. (2003) "Interfirm Cooperation and Customer Orientation", Journal of Marketing Research, 40(4), pp. $421-436$.

https://doi.org/10.1509/jmkr.40.4.421.19388

Saxe, R., Weitz, B. A. (1982) "The SOCO Scale: A Measure of the Customer Orientation of Salespeople", Journal of Marketing Research, 19(3), pp. 343-351. https://doi.org/10.2307/3151568

Schneider, S. (2001) "In Search of realistic optimism: Meaning, knowledge, and warm fuzziness", American Psychologist, 56(3), pp. 205-263.

https://doi.org/10.1037/0003-066X.56.3.250

Swenson, M. J., Hersche, J. (1994) "Social values and salesperson performance: An empirical examination", Journal of Academy of Marketing Science, 22(3), pp. 283-289.

https://doi.org/10.1177/0092070394223009

Thakor, M. V., Joshi, W. (2005) "Motivation salesperson customer orientation: insights from the job characteristics model", Journal of Business Research, 58(5), pp. 584-592. https://doi.org/10.1016/j.jbusres.2003.10.002

Zablah, A. R, Franke, G. R., Brown, T. J., Bartholomew, D. E. (2012) "How and When Does Customer Orientation Influence Frontline Employee Job Outcomes? A Meta-analytic Evaluation", Journal of Marketing, 76(3), pp. 21-40. https://oi.org/10.2307/41714487 